\title{
АНАЛІЗ ПРИЧИН НЕЗАДОВІЛЬНИХ РЕЗУЛЬТАТІВ ХІРУРГІЧНОГО ЛІКУВАННЯ ХВОРИХ НА ПОЄДНАНІ ФОРМИ ЛЕГЕНЕВОГО ТУБЕРКУЛЬОЗУ ТА РАКУ ЛЕГЕНЬ ІЗ ЗАСТОСУВАННЯМ СТАНДАРТНИХ МЕТОДИК
}

\author{
КУТОР «Тернопільський обласний протитуберкульозний диспансер»
}

๑ю. Ф. Кошак

РЕЗЮМЕ. Представлено перший в Україні аналіз незадовільних результатів хірургічного лікування хворих на поєднані форми легеневого туберкульозу та раку легень із застосуванням стандартних діагностичних та хірургічних методик. Проаналізовано морфологічні особливості поєднаних форм легеневого туберкульозу та недрібноклітинного раку легень. Показано провідний вплив легеневого туберкульозу на операційне лікування хворих на поєднані форми туберкульозу та раку легень у групі порівняння.

КЛЮчОВІ СлОВА: рак легень, туберкульоз, хірургічне лікування, діагностика.

Вступ. 3 метою вирішення завдання наукового дослідження аналізу причин незадовільних результатів хірургічного лікування хворих на поєднані форми легеневого туберкульозу (ТБ) та раку легень (НДРЛ) ми провели клінічну оцінку стандартних діагностичних методик, спрямованих на раннє виявлення раку легень у хворих на ТБ. Проаналізовано морфологічні особливості поєднаних форм туберкульозу і раку легень та вплив активного легеневого туберкульозу на результати хірургічного лікування. Встановлено, що вивчення скарг, фізикальне обстеження та СКТ без контрастування дозволяють лише запідозрити появу раку легень на фоні туберкульозного процесу. При вивченні впливу туберкульозу на хід виконання стандартних торакотомних хірургічних втручань у хворих на НДРЛ встановлено, що облітерація плевральної порожнини, фіброзно-склеротична деформація легеневої паренхіми та кореня легені, лімфатичних вузлів створюють технічні труднощі при обробці судин кореня легені, формуванні кукси бронха, що призводить до значної кількості інтра- (20,8 \%) ускладнень, які в подальшому унеможливлюють радикальне проведення лімфодисекції. Все це призводить до раннього рецидиву НДРЛ у хворих із поєднаними формами легеневого туберкульозу та раку легень.

Мета роботи: покращити результати ранньої діагностики та хірургічного лікування хворих на поєднані форми легеневого туберкульозу та НДРЛ шляхом проведення аналізу причин незадовільної ранньої діагностики та стандартних методів хірургічного лікування.

Матеріал і методи дослідження. Було проведено ретроспективний аналіз 78 випадків хворих із поєднаними формами легеневого туберкульозу та раку легень, які проходили лікування в фтизіохірургічному відділенні КУТОР «Тернопільського обласного протитуберкульозного диспансеру».

Усім хворим було проведено необхідні клінічні, лабораторні та інструментальні, включаючи рентгенологічні, методи обстеження. При аналізі діагностичних алгоритмів ми виділили їх основні групи, які дозволили запідозрити та провести діагностику виникнення раку легень на фоні туберкульозного процесу. Серед хворих груп, що вивчалися, переважали пацієнти у віці від 55 до 65 років: 32 $((84,2 \pm 1,2) \%)$ хворих в основній групі та 46 $((86,8 \pm 1,4) \%)-$ у групі порівняння. Середній вік хворих основної групи склав $(59 \pm 1,6)$ року, групи порівняння - $(61,5 \pm 1,8)$ року $(p<0,05)$.

Восновнійгрупічоловіків було $34((89,4 \pm 2,4) \%)$, В групі порівняння - $47((88,6 \pm 1,6) \%)$, жінок - 4 $((10,6 \pm 2,2) \%)$ та $6((11,4 \pm 1,5) \%)$ відповідно $(p<0,05)$.

Середня тривалість захворювання на туберкульоз у пацієнтів з моменту встановлення діагнозу до виявлення раку легені складала $(3,3 \pm 0,2)$ року в основній групі та $(3,7 \pm 0,3)$ року - в групі порівняння ( $<<0,05)$. Невелика тривалість (до 1 року) захворювання на туберкульоз у поєднанні з раком легень встановлена у $5((13,1 \pm 2,8) \%)$ пацієнтів основної групи та $6((11,3+2,2) \%)-$ в групі порівняння. Тривалий анамнез захворювання (більше 3 років) мав місце у більшості пацієнтів - у $21((55,2 \pm 2,8) \%)$ в

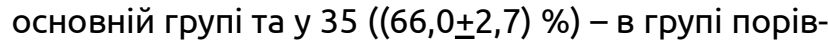
няння, що зумовлено більш значними вторинними патологічними змінами у легенях, на фоні яких розвинувся неопластичний процес. Ми вивчили результати СКТ ОГК (нативної) та виявлені основні недоліки цього методу дослідження.

Результати й обговорення. При обстеженні 78 хворих, які мали поєднані форми туберкульозу та раку легень, ретельне вивчення скарг дозволило запідозрити появу пухлинного процесу лише у 54 $((69,2 \pm 2,9) \%)$ пацієнтів $(p<0,05)$. У решти хворих скарги були відсутні або мали незначне клінічне значення. Головним чином, відмічали появу кашлю або його стійке підсилення протягом тривалого часу (не

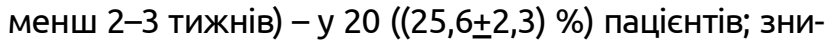
ження маси тіла більш ніж на 5-10 кг протягом 1-2

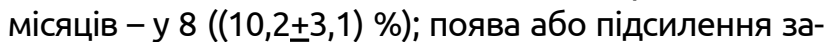

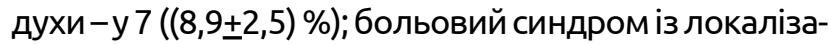
цією болю в грудній клітці-у 5 ((6,4+3,9)\%); осиплість 
Огляди літератури, оригінальні дослідження, погляд на проблему

голосу - у $4((5,1 \pm 3,9) \%) ;$ поява кровохаркання - у 4 $((5,1 \pm 2,9) \%)$; поява декількох наведених скарг одночасно - у $6((7,7 \pm 2,3) \%)(p<0,05)$.

В більшості випадків останні з перечислених симптомів з'являлися вже на пізній стадії пухлинного процесу та були зумовлені його значною розповсюдженістю з проростанням плеври (з появою ексудативного плевриту та задухи, больового синдрому), ураження гортанного нерва (осиплість голосу), навколишніх тканин, появами ателектазів легені тощо.

Таким чином, скарги не $є$ важливим діагностичним алгоритмом для ранньої діагностики поєднаних форм раку та туберкульозу легень і часто з'являються вже у пізніх стадіях раку.

Фізикальне обстеження пацієнтів також не мало суттєвої діагностичної цінності. Більшість паці$\epsilon$ нтів не мали суттєвих змін. Лише у $24((30,7 \pm 2,1) \%)$ хворих були виявлені вірогідні зміни. Так, зміна характеру мокротиння з появою малинового та іржавого кольору мала місце у $12((15,4 \pm 3,9) \%)$ пацієнтів; збільшення шийних та надключичних лімфатичних вузлів - у $5((6,4 \pm 3,9) \%)(p<0,05)$.

Центральний рак мав місце у $32((41,0 \pm 1,9) \%)$ хворих групи дослідження. При проведенні спіральної комп'ютерної томографії без контрастного підсилення вдалося виявити його характерні ознаки лише у $23((71,8 \pm 1,9) \%)$ з цих пацієнтів $(p<0,05)$. При цьому візуалізація пухлини була

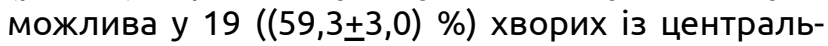
ною локалізацією раку легені, вторинні ознаки бронхостенозу та ателектазу легені - лише у 6 $((18,7 \pm 2,9) \%)(p<0,05)$. Характерна для злоякісного росту неоднорідність пухлинного вузла вияв-

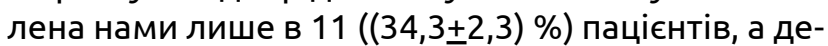

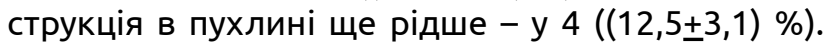
СКТ-ознаки горбистості центральної пухлини легені були чітко визначені у $9((28,1 \pm 3,0) \%)$ пацієнтів, тоді як багатовузловий тип новоутворення -

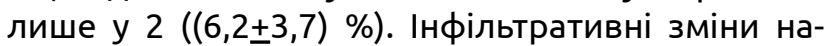
вкруги пухлинного вузла на СКТ виявлялися у 11 $((34,3 \pm 2,3)$ \%) пацієнтів, при цьому їх було важко відрізнити від інфільтрації туберкульозного походження ( $<<0,05)$.

При периферійному розташуванні недрібноклітинного раку легені, що спостерігалося у 46 $((58,9 \pm 2,3) \%)$ пацієнтів, візуалізація пухлини під час спіральної комп'ютерної томографії була дещо кращою, ніж при центральному розташуванні $(p<0,05)$. Так, характерні ознаки злоякісного росту були виявлені у 38 хворих $((82,6 \pm 1,3) \%)$, а візуалізація пухлини була можлива у $44((95,6 \pm 2,3) \%)$ випадках $(p<0,05)$. Неоднорідність пухлинного вузла при цьому відмічалася у $29((63,0 \pm 1,9) \%)$, деструкція в пухлині - у $5((10,8 \pm 3,3) \%)$, горбкува-

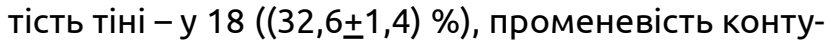
рів вузла - у $9((19,5 \pm 2,4) \%)$, багатовузловий тип пухлини виявлено у $7((15,2 \pm 2,6) \%)$ пацієнтів, а інфільтрацію навкруги первинного вузла - в 11 $((23,9 \pm 1,3) \%)$ хворих $(p<0,05)$.

Із вищевикладеного видно, що СКТ без контрастування не $\epsilon$ високочутливим методом при диференційній діагностиці пухлинного росту в легенях та загостренні туберкульозного процесу. Діагностична цінність СКТ залежала від локалізації раку та активності туберкульозу. При локалізації пухлини в зоні посттуберкульозних змін чутливість методу не перевищувала 50 \%.

Ми провели ретроспективний аналіз 30 випадків поєднання недрібноклітинного раку та туберкульозу легень із метою визначення чутливості, специфічності та точності методу спіральної комп'ютерної томографії без контрастування при оцінці метастатичного ураження внутрішньогрудних лімфатичних вузлів. Аналіз проведено за результатами СКТ до операції та за результатами інтраопераційної ревізії з подальшою біопсією та патогістологічним вивченням лімфатичних вузлів. Результати аналізу представлено в таблиці 1.

На нашу думку, низька діагностична цінність СКТ при діагностиці метастатичного ураження регіональних лімфатичних вузлів пов'язана з неможливістю розрізнити туберкульозне, пухлинне ураження, кровоносні судини, що особливо стосується медіастинальних лімфовузлів.

Фібробронхоскопія з біопсією також не дає значних позитивних результатів під час ранньої діагностики раку легені. Так, при проведенні фібробронхоскопії 63 хворим на недрібноклітинний рак легені, поєднаний з туберкульозом, лише у $23(36,5 \pm 1,7 \%)$ випадках центрального раку можна було провести верифікацію діагнозу та лише у $2((3,1 \pm 0,9) \%)$ - при периферійному раку $(p<0,05)$.

Таблиця 1. Аналіз чутливості, специфічності та точності методу СКТ без контрастування при визначенні метастатичного ураження внутрішньогрудних лімфатичних вузлів

\begin{tabular}{|l|c|c|}
\hline \multirow{2}{*}{ Критерії діагностики } & $\begin{array}{c}\text { Бронхопульмональні лімфатичні вузли } \\
\text { та вузли кореня легені }\end{array}$ & Медіастинальні лімфатичні вузли \\
\cline { 2 - 3 } & \multicolumn{2}{|c|}{ абсолютні показники } \\
\hline Чутливість (\%) & 31 & 22 \\
\hline Специфічність (\%) & 45 & 34 \\
\hline Точність (\%) & 49 & 38 \\
\hline
\end{tabular}


Огляди літератури, оригінальні дослідження, погляд на проблему

Цитологічне дослідження мокротиння, у тому числі при виконанні ФБС, не мало значної діагностичної цінності та дозволило виявити атипові клітини лише у 18,7 \% хворих на центральний рак легені, поєднаний з туберкульозом, та у 2,9 \% - при периферійному недрібноклітинному раку.

І 78 хворих на поєднані форми раку та туберкульозу легень, що увійшли в дослідження, лише у 53 (67,9 \%) НДРл був вірогідно діагностований своєчасно та ці пацієнти підлягали радикальному хірургічному лікуванню, склавши групу порівняння даного наукового дослідження. Решта пацієнтів була визнана неоперабельною внаслідок пізніх стадій (IIIB-IV) пухлинного процесу. Розподіл хворих за стадіями раку представлено в таблиці 2.

Таким чином, при ретроспективному аналізі незадовільних результатів пізньої діагностики раку легень у хворих на туберкульоз встановлено низьку ефективність стандартних методів діагностики. Застосування спіральної КТ ОГК без контрастування, фібробронхоскопії та цитологічного дослідження мокротиння має низьку чутливість, специфічність та точність, що дозволило правильно встановити діагноз на доопераційному етапі лише у 27,4 \% пацієнтів. Застосування інших стандартних методів обстеження, таких як вивчення скарг, анамнезу, фізикальних даних, рентгенологічне та томографічне дослідження, має низьку діагностичну цінність та в більшості випадків $\epsilon$ ефективним лише на пізніх стадіях захворювання.

В усіх хворих обох груп спостереження обов'язковим було проведення патогістологічного дослідження біопсійного матеріалу та резектатів легені й лімфатичних вузлів. Ми провели розподіл клінічних випадків на 3 категорії (табл. 3):

1. Рак на фоні посттуберкульозних змін та так званий «рак в рубці».

2. Рак в туберкульомі.

3. Рак у стінці санованої туберкульозної каверни.

Залишкові зміни туберкульозного процесу були малими (фіброз, щільні вогнища, петрифікати, невеликі сановані каверни) - 39 (42,9\%) та великими 19 (20,8 \%) -у вигляді грубого розповсюдженого фіброзу, цирозу, склеротичних змін, великих санованих каверн, конгломератів вогнищ, великих туберкульом (понад 3 см), розповсюджених щільних вогнищ). Розташування посттуберкульозних змін було здебльшого у верхніх частках легень.

Гістологічно посттуберкульозні зміни були представлені переважно склерозом із поодинокими гранульомами, в препаратах переважала груба волокниста сполучна тканина. Іноді зустрічалися

Таблиця 2. Стадії раку у хворих групи порівняння

\begin{tabular}{|l|c|c|}
\hline \multirow{2}{*}{ Стадії раку легені НдРл } & \multicolumn{2}{|c|}{ Хворі групи порівняння } \\
\cline { 2 - 3 } & a6с. & \% \\
\hline I A & 3 & 3,8 \\
\hline I B & 4 & 30,7 \\
\hline II A & 24 & 24,3 \\
\hline II B & 19 & 3,8 \\
\hline III A & 3 & 12,8 \\
\hline III B & 10 & 19,5 \\
\hline IV & 15 & $100 \%$ \\
\hline Усього & 78 & \\
\hline
\end{tabular}

Таблиця 3. Морфологія поєднаних форм туберкульозу та раку легень у хворих груп спостереження (Mm)\%

\begin{tabular}{|c|c|c|c|c|}
\hline \multirow{2}{*}{ Морфологічні форми } & \multicolumn{2}{|c|}{ Основна група $(n=38)$} & \multicolumn{2}{|c|}{ Група порівняння (n=53) } \\
\hline & a6c. & $\%$ & a6c. & $\%$ \\
\hline Рак в посттуберкульозних змінах: & 31 & $81,6+2,6^{*}$ & 46 & $86,7+1,8^{*}$ \\
\hline Фі6роз & 4 & $10,5+2,2 *$ & 6 & $11,3+2,7^{*}$ \\
\hline Цироз & 3 & $7,8+0,1^{*}$ & 4 & $7,5+0,6^{*}$ \\
\hline Щільні вогнища & 6 & $15,7+1,0 *$ & 8 & $15,1+3,2^{*}$ \\
\hline Конгломерати вогнищ & 5 & $13,1+3,6^{*}$ & 7 & $13,2+3,2 *$ \\
\hline Неактивні туберкуломи & 8 & $21,0+5,2 *$ & 11 & $20,7+2,4^{*}$ \\
\hline Сановані каверни & 5 & $13,1+2,9 *$ & 10 & $18,8+3,9 *$ \\
\hline Рак в активній туберкульомі & 3 & $7,8+2,1^{*}$ & 4 & $7,5+2,3 *$ \\
\hline Рак в стінці каверни & 4 & $10,5+2,6^{*}$ & 3 & $5,67+1,8 *$ \\
\hline $\mathrm{P}$ & \multicolumn{4}{|c|}{$p<0,05$} \\
\hline
\end{tabular}

Примітка. * p - рівень значимості за критерієм х² Пірсона в основній групі та групі порівняння (р>0,05). 
вогнища кальцифікації та відкладання кристалів холестерину. Зустрічалися ділянки гіалінозу та антракотичні включення, особливо в субплевральному шарі. Важливою ознакою посттуберкульозних рубцевих змін легені $\epsilon$ утворення поліморфних порожнин, що доволі часто об'єднуються між собою та вкриті епітелієм. Клітини епітелію $\epsilon$ залишком альвеол та бронхіол, що замкнуті в оточенні фіброзу. Крім того, виявляються розширені залишки альвеол з атиповою проліферацією епітелію у вигляді поліпів. На нашу думку, саме ці клітини епітелію відіграють основну роль в утворенні первинного пухлинного вузла.

Легеневий туберкульоз активно впливає на операційне лікування хворих на поєднані форми туберкульозу та раку легень у групі порівняння. При лікуванні поєднання НДРЛ з туберкульозом у 53 хворих групи порівняння найчастіше використовували задньо-бокова торакотомію. Ревізія плевральної порожнини ускладнювалась наявністю плевральних зрощень і змін у легеневій тканині та лімфовузлах, що виникли на фоні туберкульозної інфекції чи перенесеного туберкульозного плевриту. Розділення зрощень збільшує час операційного втручання та інтраопераційну крововтрату, утруднює мобілізацію кореня легені та ревізію середостіння. В групі порівняння плевральна порожнина була повністю облітерована у 10,2 \% хворих, частково облітерована у $17,2 \%$, в 47,6 \% пацієнтів спостерігалися множинні плевральні зрощення, одиничні - в 9,8 \%; плевральна порожнина була вільною від зрощень у 15,2 \% хворих.

У 75 \% випадків для виділення легені із зрощень застосували екстраплевральний пневмоліз. У 25 \% випадків оперовану легеню виділяли із злук інтраплеврально. У 6 хворих спостерігали розвиток раку легені в оперованій раніше легені 3 приводу туберкульозу. В цих випадках у плевральній порожнині виникли масивні рубцеві злуки, які було дуже складно розділити. Серед 36 пневмонектомій, що були виконані у хворих групи порівняння, у 6 (16,7 \%) виконували так звану заключну пневмонектомію. При цьому об'єм інтраопераційної крововтрати під час підходу до елементів кореня легені складав у середньому $(1352,8 \pm 63,4)$ мл. 17 хворим групи порівняння виконано розширену лобектомію з середнім об'ємом інтраопераційної крововтрати $(639,8 \pm 27,3)$ мл $(p>0,05)$.

У групі порівняння в ранньому післяопераційному періоді померли 2 (3,8 \%) хворих внаслідок тромбоемболії легеневої артерії та емпієми плеври з бронхіальною норицею після пневмонектомії. у 2 випадках була потрібна реторакотомія у зв'язку з формуванням гемотораксу, що згорнувся в післяопераційному періоді. В одному випадку у зв'язку зі сповільненим розправленням легені і формуванням залишкової порожнини було потрібне виконання коригуючої торакопластики.

Таким чином, при ретроспективному аналізі 53 операцій (17 лобектомій і 36 пневмонектомій) у хворих на поєднані форми туберкульозу та раку легень звертає на себе увагу висока $(20,8 \%)$ питома вага інтраопераційних та післяопераційних ускладнень (26,4 \%) при виконанні операційних втручань із використанням стандартної латеральної торакотомії.

Висновки. У 78 хворих на поєднані форми раку та туберкульозу легень лише у 67,9 \% рак був діагностований своєчасно, тобто на стадії можливого радикального хірургічного лікування. Аналіз діагностичної цінності методів діагностики раку легень у хворих на туберкульоз показав, що своєчасне виявлення такого поєднання становить значні труднощі. Найбільші діагностичні труднощі зустрічаються у пацієнтів із локалізацією раку в зоні активних туберкульозних або посттуберкульозних змін. У 32 \% хворих поєднання раку легень та туберкульозу діагностується на пізній стадії пухлинного процесу. При вивченні впливу туберкульозу на хід виконання стандартних фтизіохірургічних втручань у хворих на рак легень встановлено, що облітерація плевральної порожнини, значна фіброзносклеротична деформація паренхіми та кореня легені, лімфатичних вузлів створюють технічні труднощі при обробці судин кореня легені, проведенні лімфодисекції, що призводить до значної кількості інтра- $(20,8 \%)$ та післяопераційних $(26,4 \%)$ ускладнень.

Перспективи подальших досліджень полягають в удосконаленні операційної лімфодисекції при недрібноклітинному раку легень з використанням медіастинального доступу.

\section{ЛІТЕРАТУРА}

1. Бисенков Л. Н. Хирургия далеко зашедших и осложненных форм рака легкого / Л. Н. Бисенков, А. С. Барчук, Г. М. Бояркин ; под ред. Л. Н. Бисенкова. СПб. : ДЕАН, 2006. - 431С.

2. Венцявичюс В. Возможности хирургического лечения при сочетании туберкулеза и рака легкого /
В. Венцявичюс, С. Циценас, Р. Тикуйшис // Пробл. туберкулеза и болезней легких. - 2007. - № 5. - С. 32-36.

3. Перельман М.И. Рак легкого / М. И. Перельман // Пробл. туберкулеза и болезней легких. - 2005. - № 6. - C. 10-20.

4. Савенков Ю. Ф. Транстернальная заключитель- 
Огляди літератури, оригінальні дослідження, погляд на проблему

ная пневмонэктомия у больных туберкулезом при раке ранее оперированного легкого // Укр. пульмонол. журнал. - 2002. - № 1. - С. 58-59.

5. Тарасов В. А. Специфика хирургического лечения немелкоклеточного рака легких в сочетании с туберкулезом / В. А. Тарасов, Г. М. Бояркин // Вопр. онкологи. - 2006. - № 6. - С. 616-619.

6. Ashizawa K. Coexistence of lung cancer and tuberculoma in the same lesion:demonstration by high resolution and contrast-enhanced dynamic CT/ K. Ashizawa // British Journal of Radiology. - 2004. - Vol. 77. - P. 959-962.

7. High-resolution CT findings of diffuse branehioloalveolar carcinoma in 38 patients / M. Akira, S. Atagi, M. Kawahara [et al.] // AJR Am. J. Roentgenol. - 1999. Vol. 173, № 6. - P. 1623-1629.

8. Scar carcinoma of the lung: historical perspective / R. K. Bobba, J. S. Holly, T. Loy, M. C. Perry // Clinical Lung Cancer. - 2011. -Vol. 12. - P. 148-154.

9. Bhatt M. L. B. Pulmonary tuberculosis as differential diagnosis of lung cancer / M. L. B. Bhatt // Diagnostic dilemia. - 2012. - Vol.1, No. 1. - P. 36-42.
10. Brenner D. R. Previous lung diseases and lung cancer risk: a systematic review and meta-analysis / D. R. Brenner, J. R. Laughlin, R. J. Hung// PLOSONE. -2011. -Vol. 6. -P. 17479.

11.CicenasS. Lung cancerin patientswithtuberculosis/ S. Cicenas // World Journal of Surgical Oncology. - 2007. - № 5. - P. 22.

12. Coexistent Lung Carcinoma and Active Pulmonary Tubeculosis in the Same Lobe / M. Sakuraba, M. Hirama, A. Hebisava [et al.] // Ann. Thoracic. Cardiovasc. Surg. 2006. - Vol. 12, No. 1. - P. 53-55.

13. Dragica P. Pesut Lung Cancer and Pulmonary Tuberculosis - a comparative population-genetic study / D. P. Pesut, D. M. Marinkovic // Balkan Journal of Medical Genesis. - 2009. - Vol. 12, No. 2. - P. 45-52.

14. Tuberculosis and risk of cancer: a Danish nationwide cohort study / D. F. Simonsen, D. K. Farkas, M. Segaard [et al.] // Int. J. Tuberc. Lung Dis. - 2014. Vol. 18 (10). - P. 1211-1219.

15. Vento S. Tuberculosis and cancer: a complex and dangerous liaison / S. Vento, M. Lanzafame // Lancet Oncol. - 2011. - Vol. 12. - P. 520-522.

\section{ANALYSIS OF CAUSES OF UNSATISFACTORY RESULTS OF SURGICAL TREATMENT OF PATIENTS WITH COMBINED FORMS OF PULMONARY TUBERCULOSIS AND LUNG CANCER WITH THE USE OF STANDARD METHODS}

OYu. F. Koshak

\section{Ternopil Regional Antituberculous Hospital}

SUMMARY. The first in Ukraine analysis of the unsatisfactory results of surgical treatment of patients with combined forms of pulmonary tuberculosis and lung cancer with the use of standard diagnostic and surgical techniques is presented. The morphological features of combined forms of pulmonary tuberculosis and non-small cell cancer were analyzed. It is shown the leading effect of pulmonary tuberculosis on the surgical treatment of patients with combined forms of tuberculosis and lung cancer in the comparison.

KEY WORDS: lung cancer, tuberculosis, surgical treatment, diagnostics. 